\title{
2,4-Di-tert-butil-5,6-dialkylpyrimidines: easily prepared alternative to non-nucleophilic hindered bases
}

\author{
Antonio Herrera-Fernández, ${ }^{\text {a }}$ Roberto Martínez-Alvarez, ${ }^{\text {a }}$ Mourad Chioua, ${ }^{a}$ \\ Rachid Chioua, ${ }^{b}$ John Almy, ${ }^{c}$ and O. A. Loaiza ${ }^{\text {d }}$ \\ ${ }^{a}$ Departamento de Química Orgánica, Facultad de Ciencias Químicas, Universidad \\ Complutense, E-28040 Madrid, Spain \\ ${ }^{b}$ Département de Chimie, Université Abdelmalek Essaâdi, Faculté des Sciences, Tétouan, \\ Morocco \\ ${ }^{c}$ Department of Chemistry, California State University, Stanislaus, Turlock, CA 95382, USA \\ ${ }^{d}$ Departamento de Química Analítica, Facultad de Ciencias Químicas, Universidad \\ Complutense, E-28040 Madrid, Spain \\ E-mail: aherrera@quim.ucm.es
}

\begin{abstract}
2,4-Di-tert-butyl-5,6-dialkylpyrimidines were easily obtained in a one-step reaction from dialkyl ketones and pivalonitrile in the presence of triflic anhydride. $\mathrm{pKa}$ values determined show that these compounds can be used as highly sterically non-nucleophilic bases. It was applied to the synthesis of vinyl triflates in which the strong $\mathrm{TfOH}$ acid is formed. The results were compared with the obtained using commercially available 2,4,6-tri-tert-butylpyrimidine (TTBP).
\end{abstract}

Keywords: Non-nucleophilic bases, pyrimidines, vinyl triflates

\section{Introduction}

Bases are a very important class of reagents for synthetic organic chemistry, as in a large amount of reactions the deprotonation is a key step in the synthesis of new structures. Different applications and reaction conditions often require the use of specific bases. Due to this, a broad range of organic bases have been developed and commonly used. These bases are differenciated by strengh, nucleophilicity, steric hindrance or solubility. Many efforts have been made in optimizing the basicity and reducting the nucleophilic character of organic bases. Thus, steric hindered aliphatic amines, anilines and $N$-heterocycles have been widely applied and shown a couple of useful applications as i.e. in Dieckmann cyclization, ${ }^{1}$ polymerizations ${ }^{2}$ or metalation reactions. $^{3}$ In this regard, 2,6-di-tert-butyl-4-alkyl-pyridines (1) were introduced by Brown and Kanner $^{4}$ as a non-nucleophilic mild bases (Figure 1). 


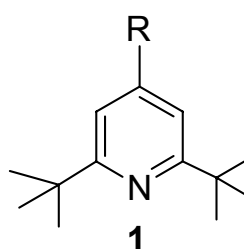

1

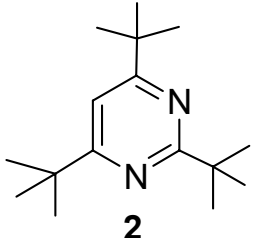

2<smiles>[R]c1nc(C(C)(C)C)nc(C(C)(C)C)c1[R]</smiles>

3

\section{Figure 1}

Compounds (1) have been extensively employed in a broad variety of contexts ${ }^{5,6}$ mainly the formation of vinyl triflates ${ }^{7,8}$ in spite of their multi-step preparation. More recently Crich et al. ${ }^{9}$ reported that 2,4,6-tri-tert-butylpyrimidine (TTBP, 2) serves as an "admirable" replacement for (1) in the mentioned reactions. Additionally high amounts of 2 can be easily obtained following the improved procedure developed by us, ${ }^{10}$ which permits the synthesis of a large number of tetraalkyl-, tetraaryl- and alkyl-arylpyrimidines in high yield. Thus, the synthesis of (2) involves the condensation of pinacolone (4) with two equivalents of pivalonitrile, promoted by one equivalent of trifluoromethanesulfonic anhydride (triflic anhydride, $\mathrm{Tf}_{2} \mathrm{O}$ ). The reaction was carried out at $25^{\circ} \mathrm{C}$ in dichloromethane as solvent. Unpolar solvents such as $n$-pentane or carbon tetrachloride can also be used (Scheme 1). ${ }^{10}$

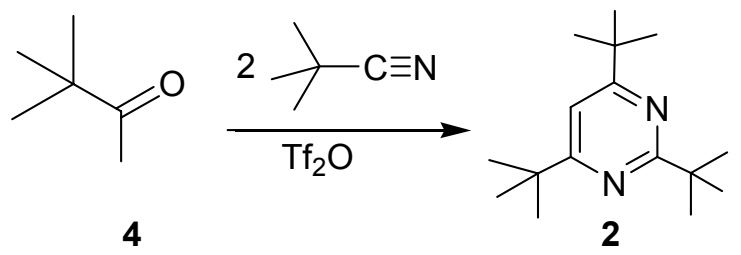

\section{Scheme 1}

We now report the synthesis of new substituted 2,4-di-tert-butil-5,6-dialkylpyrimidines (3) following the general procedure developed by us. ${ }^{10}$ Its $\mathrm{pKa}$ values were determined and its application as non-nucleophilic bases in the formation of vinyl triflates studied.

\section{Results and Discussion}

The reaction of symmetric ketones (5) with 2 equivalents of pivalonitrile (Scheme 2) at $25^{\circ} \mathrm{C}$ in dichloromethane as solvent affords substituted pyrimidines (3) as the unique reaction product (Scheme 2). Symmetric ketones were chosen as starting products since only one regioisomer can be produced. Good yields were obtained (Table 1). 


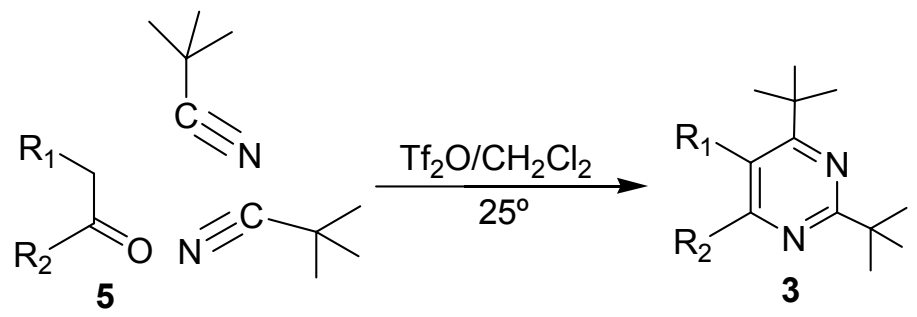

\section{Scheme 2}

Table 1. 2,4-Di-tert-butyl-5,6-dialkylpyrimidines (3) prepared

\begin{tabular}{cccc}
\hline \multicolumn{2}{c}{ Ketone $\mathbf{5}$} & Compound & Yield (\%) ${ }^{\mathrm{a}}$ \\
\hline a & $\mathrm{R}^{1}=\mathrm{Me}, \mathrm{R}^{2}=\mathrm{Et}$ & 3a & 73 \\
b & $\mathrm{R}^{1}=\mathrm{Et}, \mathrm{R}^{2}=\mathrm{Pr}$ & $\mathbf{3 b}$ & 77 \\
c & $\mathrm{R}^{1}=\mathrm{Pr}, \mathrm{R}^{2}=\mathrm{Bu}$ & $\mathbf{3 c}$ & 70 \\
\hline
\end{tabular}

${ }^{\text {a }}$ Yield of isolated product.

2,4-Di-tert-butyl-5,6-dialkylpyrimidines (3a-c) were tested as non-nucleophilic bases by means of their use in the synthesis of the cyclohexenyl triflate (7), were triflic acid is generated as byproduct (Scheme 3). In comparison with 2,4,6-tri-tert-butilpyrimidine (2) slightly higher yields were obtained. pKa values of new 2,4-di-tert-butylpyrimidines 3a-c were determined using Differencial Pulse Polarography (DPP) and compared with 2.

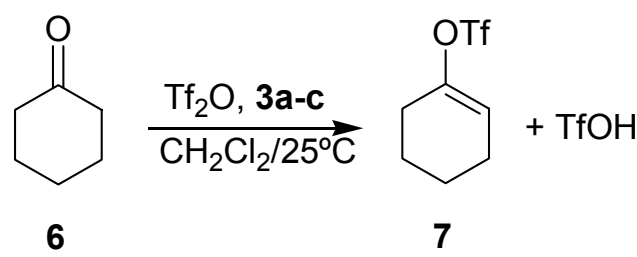

\section{Scheme 3}

As shown in Table 2, pKa values of new 2,4-di-tert-butyl-5,6-dialkylpyrimidines (3a-c) are higher than this from 2,4,6-tri-tert-butylpyrimidine (2). Although new bases (3a-c) are milder than (2), its basicity is sufficient to neutralize triflic acid, the byproduct originated in enol triflate formation and in a couple of reactions for which triflic anhydride is used as reagent. The absence of water in the reaction media avoids the total dissociation of TfOH. ${ }^{11}$ However it is necessary to trap the formed acid because its presence provokes a partial decomposition of final products. 
Table 2. pKa of pyrimidines (2, 3a-c ) and yield of vinyl triflate 7 obtained

\begin{tabular}{ccc}
\hline Compound & $\mathrm{pKa}$ & Yield (\%) \\
\hline $\mathbf{2}$ & 1.07 & 62 \\
$\mathbf{3 a}$ & 1.95 & 64 \\
$\mathbf{3 b}$ & 1.68 & 67 \\
$\mathbf{3 c}$ & 1.61 & 71 \\
\hline
\end{tabular}

In comparation with the already known 2,4,6-tri-tert-butylpyrimidine (2), the preparation of 2,4-di-tert-butil-5,6-dialkylpyrimidines (3a-c) is easier and the costs are lower. The above shown results obtained in the synthesis of cyclohexenyl triflate (7) are slight better. In summary we propose that 2,4-di-tert-butyl-5,6-dialkylpyrimidines (3a-c) easily synthesized in a one-step reaction from symmetric ketones offers new base-candidates to be used as non-nucleophilic bases replacing 2,4,6-tri-tert-butylpyrimidine (TTBP) (2).

\section{Experimental Section}

General Procedures. All reagents were commercial grade and were used as received unless otherwise indicated. Triflic anhydride was prepared from $\mathrm{TfOH}$ and redistilled twice prior to use. $^{12,13}$ Solvents were distilled from an appropriate drying agent before use. Reactions were monitored by thin-layer chromatography. Column chromatography was performed using silica gel 60. IR, NMR, Mass spectra and Elemental Analysis were carried out in the CAIs of the UCM. The IR spectra were measured with a Shimadzu FTIR 8300 instrument. NMR spectra were recorded on a Bruker DPX 300 and Bruker Avance AV 500 at $300 \mathrm{MHz}$ for ${ }^{1} \mathrm{H}$ and 75.47 $\mathrm{MHz}$ for ${ }^{13} \mathrm{C}$ and $500 \mathrm{MHz}$ for ${ }^{1} \mathrm{H}$ and $125.72 \mathrm{MHz}$ for ${ }^{13} \mathrm{C}$ respectively. Chemical shifts are given in $\delta$ units (ppm) to residual $\mathrm{CHCl}_{3}$ (7.26 and 77.0 respectively). $J$ values are given in $\mathrm{Hz}$. Mass spectra (EI) were recorded on a HP 5989A quadrupole instrument at $70 \mathrm{eV}$ with a source temperature of $200{ }^{\circ} \mathrm{C}$. Elemental analyses were performed with a Perkin-Elmer $2400 \mathrm{CHN}$ apparatus.

\section{General procedure for the synthesis of 2,4-di-tert-butyl-5,6-dialkyl substituted pyrimidines}

To a well-stirred solution of triflic anhydride $(6.4 \mathrm{~g}, 22.8 \mathrm{mmol})$ and pivalonitrile $(3.0 \mathrm{~g}, 42$ mmol) in anhydrous $\mathrm{CH}_{2} \mathrm{Cl}_{2}(20 \mathrm{~mL})$ was added slowly a solution of the ketone 5 (20 mmol) in anhydrous $\mathrm{CH}_{2} \mathrm{Cl}_{2}(10 \mathrm{~mL})$. The red-brown mixture was magnetically stirred for $24 \mathrm{~h}$ at room temperature. Saturated $\mathrm{NaHCO}_{3}$ solution $(50 \mathrm{~mL})$ was carefully added, and the organic phase was washed with brine $(2 \times 50 \mathrm{~mL})$ and dried over $\mathrm{MgSO}_{4}$. The solvent was removed in vacuo, and the crude product was purified by column chromatography over silica gel 60 (Merck) using hexane/ethyl acetate $(9: 1)$ as the eluent.

2,4-Di-tert-butyl-6-ethyl-5-methylpyrimidine (3a). Bp $100-101{ }^{\circ} \mathrm{C}\left(0.4\right.$ Torr); IR $\left(\mathrm{CHCl}_{3}\right)$ v: 2956, 2871, 1541, 1448, 1012, $923 \mathrm{~cm}^{-1} ;{ }^{1} \mathrm{H} \mathrm{NMR}\left(\mathrm{CDCl}_{3}\right) \delta: 1.30\left(\mathrm{t}, J=7.5 \mathrm{~Hz}, 3 \mathrm{H}, \mathrm{CH}_{3}\right)$, 
$1.39\left(\mathrm{~s}, 9 \mathrm{H}, 3 \mathrm{CH}_{3}\right), 1.44\left(\mathrm{~s}, 9 \mathrm{H}, 3 \mathrm{CH}_{3}\right), 2.37\left(\mathrm{~s}, 3 \mathrm{H}, \mathrm{CH}_{3}\right), 2.76\left(\mathrm{q}, J=7.5 \mathrm{~Hz}, 2 \mathrm{H}, \mathrm{CH}_{2}\right) ;{ }^{13} \mathrm{C}$ $\operatorname{NMR}\left(\mathrm{CDCl}_{3}\right) \delta: 12.03,15.10,28.40,29.69,29.70,39.14,112.59,169.15,171.44,171.81 \mathrm{ppm}$; MS (EI, $70 \mathrm{eV}) \mathrm{m} / \mathrm{z}(\% \mathrm{~B}): 234\left(\mathrm{M}^{+\bullet}, 4\right), 233$ (4), 219 (11), 205 (5), 192 (28), 102 (13), 97 (15), 71 (35), 57 (100), 44 (99); ; Anal. Calcd for $\mathrm{C}_{15} \mathrm{H}_{26} \mathrm{~N}_{2}, \mathrm{C} 76.87 \% \mathrm{H} 11.18 \% \mathrm{~N} 11.95 \%$. Found C $78.81 \%$ H 10.90 N 11.57\%.

2,4-Di-tert-butyl-5-ethyl-6-propylpyrimidine (3b). Bp $120-121{ }^{\circ} \mathrm{C}\left(0.6\right.$ Torr); IR $\left(\mathrm{CHCl}_{3}\right)$ v: 2958, 2927, 1537, 1479, $1055 \mathrm{~cm}^{-1} ;{ }^{1} \mathrm{H}$ NMR $\left(\mathrm{CDCl}_{3}\right) \delta: 1.01\left(\mathrm{t}, J=7.3 \mathrm{~Hz}, 3 \mathrm{H}, \mathrm{CH}_{3}\right), 1.18(\mathrm{t}$, $\left.J=7.3 \mathrm{~Hz}, 3 \mathrm{H}, \mathrm{CH}_{3}\right), 1.36$ (s, $\left.9 \mathrm{H}, 3 \mathrm{CH}_{3}\right), 1.42\left(\mathrm{~s}, 9 \mathrm{H}, 3 \mathrm{CH}_{3}\right), 1.81$ (sext, $J=7.3 \mathrm{~Hz}, 2 \mathrm{H}, \mathrm{CH}_{2}$ ), $2.71\left(\mathrm{t}, J=7.3 \mathrm{~Hz}, 2 \mathrm{H}, \mathrm{CH}_{2}\right), 2.85\left(\mathrm{q}, J=7.3 \mathrm{~Hz}, 2 \mathrm{H}, \mathrm{CH}_{2}\right) ;{ }^{13} \mathrm{C} \mathrm{NMR}\left(\mathrm{CDCl}_{3}\right) \delta: 14.35,15.25$, 21.17, 22.15, 29.77, 30.68, 35.99, 39.17, 39.77, 128.28, 168.64, 171.49, 171.73 ppm; MS (EI, 70 eV) $m / z(\% \mathrm{~B}): 262\left(\mathrm{M}^{+}\right.$, 4), 245 (62), 219 (7), 205 (27), 191 (14), 71 (19), 57 (61), 44 (100) ; Anal. Calcd for $\mathrm{C}_{17} \mathrm{H}_{30} \mathrm{~N}_{2}$, C 77.80\% H 11.52\% N 10.67\%. Found C 77.71\% H 11.65 N 10.34\%.

4-Butyl-2,4-di-tert-butyl-5-propylpyrimidine (3c). Bp $150-151{ }^{\circ} \mathrm{C}$ (0.6 Torr); IR $\left(\mathrm{CHCl}_{3}\right)$ v: 2958, 2929, 1533, 1402, 1215, 1089, $908 \mathrm{~cm}^{-1} ;{ }^{1} \mathrm{H} \mathrm{NMR}\left(\mathrm{CDCl}_{3}\right) \delta: 0.96$ (t, $J=7.3 \mathrm{~Hz}, 3 \mathrm{H}$, $\left.\mathrm{CH}_{3}\right), 1.05\left(\mathrm{t}, J=7.3 \mathrm{~Hz}, 3 \mathrm{H}, \mathrm{CH}_{3}\right), 1.35\left(\mathrm{~s}, 9 \mathrm{H}, 3 \mathrm{CH}_{3}\right), 1.41\left(\mathrm{~s}, 9 \mathrm{H}, 3 \mathrm{CH}_{3}\right), 1.64\left(\mathrm{~m}, 6 \mathrm{H}, 3 \mathrm{CH}_{2}\right)$, $2.71\left(\mathrm{~m}, 4 \mathrm{H}, 2 \mathrm{CH}_{2}\right) ;{ }^{13} \mathrm{C}$ NMR $\left(\mathrm{CDCl}_{3}\right) \delta: 14.06,14.63,22.82,24.19,29.62,30.51,30.71$, 31.04, 33,70, 39.02, 39.64, 126.84, 168.77, 171.37, 171.56 ppm; MS (EI, $70 \mathrm{eV}) \mathrm{m} / z$ (\%B): 290 $\left(\mathrm{M}^{+\bullet}, 3\right), 289$ (4), 276 (16), 275 (86), 261 (30), 247 (68), 233 (40), 219 (19), 206 (20), 191 (22), 178 (10), 97 (17), 81 (16), 71 (39), 69 (39), 57 (100), 42 (44); Anal. Calcd for $\mathrm{C}_{19} \mathrm{H}_{34} \mathrm{~N}_{2}, \mathrm{C}$ $78.56 \%$ H $11.80 \%$ N 9.64\%. Found C 78.51\% H 11.90 N 9.57\%.

\section{Synthesis of cyclohexenyl triflate (7) in the presence of 4-butyl-2,4-di-tert-butyl-5- propylpyrimidine (3c)}

To a stirred solution of cyclohexanone (6) $(2 \mathrm{~g}, 20.4 \mathrm{mmol})$ and pyrimidine (3c) $(6,67 \mathrm{~g}, 23$ mmol) in anhydrous $\mathrm{CH}_{2} \mathrm{Cl}_{2}(20 \mathrm{~mL})$ was added dropwise a solution of triflic anhydride $(6.31 \mathrm{~g}$, $22.4 \mathrm{mmol})$ in anhydrous $\mathrm{CH}_{2} \mathrm{Cl}_{2}(20 \mathrm{~mL})$ at $0^{\circ} \mathrm{C}$. The reaction mixture was stirred at room temperature for $24 \mathrm{~h}$. The solvent was removed in vacuo and the residue extracted with hexane $(3 \times 50 \mathrm{~mL})$. The hexane extract was washed with $1.5 \mathrm{M}$ aqueous hydrochloric acid $(2 \times 50 \mathrm{~mL})$, saturated with sodium hydrogen carbonate solution $(2 \times 50 \mathrm{~mL})$ and saturated brine $(2 \times 50 \mathrm{~mL})$. The organic layer was dried with magnesium sulfate and the solvent removed under vacuum. The residue was purified by column chromatography using hexane as the eluent. $3.3 \mathrm{~g}(71 \%)$ of triflate (7) were obtained. ${ }^{13}$

\section{Determination of pKa values}

\section{Electrodes and electrochemical cell}

The electrochemical cell consisted of a multimode Metrohm 6.1246.020 Hg electrode equipped with a Metrohm 6.1226.030 capillary tube and operated in the DME mode, a Metrohm 6.0728.000 Ag/AgCI/3 mol L ${ }^{-1} \mathrm{KCI}$ reference electrode, and a Metrohm 6.1247.000 auxiliary glassy carbon electrode, in a Metrohm 6.1415.0210 vessel.

A Metrohm AG-9100 combined electrode was used for $\mathrm{pH}$ measurements. 


\section{Reagents and solutions: Procedure}

DP polarograms were recorded in $1.0 \times 10^{-5} \mathrm{~mol} \mathrm{~L}^{-1}$ solutions of each compound in a BrittonRobinson buffer solution containing each component acid at $0.2 \mathrm{~mol} \mathrm{~L}^{-1}(\mathrm{pH}$ range $0.5-4.0$ ) and with a $6 \%$ content in ethanol. The prepared solutions $(25 \mathrm{~mL})$ were transferred into the electrochemical cell and deoxygenated by passing an argon stream through them for $15 \mathrm{~min}$. Polarograms were recorded at $25 \pm 1{ }^{\circ} \mathrm{C}$ keeping an inert atmosphere in the cell, with $\Delta \mathrm{E}=-50$ $\mathrm{mV}, \mathrm{v}=10 \mathrm{mV} \mathrm{s}^{-1}$, and $\mathrm{t}_{\mathrm{d}}=1 \mathrm{~s}$.

DPP allows the achievement of polarograms (current-potential plots at the dropping mercury electrode) when a pulse train of constant amplitude is superimposed to a steadily varying with the time potential program, in the buffer solution containing the sample. The peak potential decreased only slightly between $\mathrm{pH}$ 0.5-2.0 in all cases, while a strongly $\mathrm{pH}$ dependence between $\mathrm{pH}$ 2.0-4.0 was found (Fig. not shown). A plot of the influence of $\mathrm{pH}$ on the peak potentials obtained, gives various linear regions whose intersection points can be associated to the $\mathrm{pKa}$ value of each studied compound. The RSDs values for each measured compound were lower than $5 \%$ in all cases.

\section{Acknowledgements}

We gratefully acknowledge the MEC (Spain, grant CTQ2006-02444/BQU and Project Consolider Ingenio 2007) for financial support. We also thank the CAIs of the UCM for recording spectra and $\mathrm{CHN}$ analyses.

\section{References}

1. See for example: Cuny, G. D.; Lee, K.; Choi, S. Lett. Org. Chem. 2006, 3(1), 68.

2. Simison, K. L.; Stokes, C. D.; Harrison, J. J.; Storey, R. F. Macromolecules 2006, 39(7), 2481.

3. Collman, J. P.; Wang, H. J. H.; Decreau, R. A.; Eberspacher, T. A.; Sunderland, C. J.; Chem. Comm. 2005, 19, 2497.

4. Brown, H. C.; Kanner, B. J. Am. Chem. Soc. 1953, 75, 3865.

5. 2,6-Di-tert-butylpyridine In Encyclopedia of Reagents for Organic Synthesis; Paquette, L. A., Ed.; Wiley: Chichester, 1995; Vol. 3, p 1623.

6. Yan, L.; Kahne, D. J. Am. Chem. Soc., 1996, 118, 9239.

7. Wright, M. E.; Pulley, S. R. J. Org. Chem., 1989, 54, 2886.

8. Stang, P. J.; Treptow, W. Synthesis 1980, 283.

9. Crich, D.; Smith, M.; Yao, Q.; Picione, J. Synthesis 2001, 2, 323.

10. García Martínez, A.; Herrera-Fernández, A.; Moreno Jiménez, F.; García Fraile, A.; Subramanian, L. R.; Hanack, M. J. Org. Chem., 1992, 57, 1627. 
11. Paddison, S. J.; Pratt, L. R.; Zawodzinski Jr, T. A. J. Phys. Chem. A 2001, 105, 6266.

12. Stang, P. J.; Dueber, T. E. Org. Synth. 1974, 54, 79.

13. Stang, P. J.; Hanack, M.; Subramanian, L. R. Synthesis 1982, 85. 